Research Article

\title{
Investigating Error in Written English Sentences: A case study Indonesia EFL Students
}

\author{
Ahmad Sunandar, Ratna Susanti* \\ Department of Medical Records, Polytechnical of Indonusa Surakarta 57149, Indonesia
}

Article history:

Submission June 2020

Revised August 2020

Accepted August 2020

${ }^{*}$ Corresponding author:

E-mail:

ratnasusanti19@poltekindonusa.ac.id

\begin{abstract}
Introduction: This research was conducted to find out the students' grammatical errors in writing and focused on the types of errors found in 20 written sheets of students' descriptive text given as a part of the assignment of the second semester of Polytechnic Indonusa Surakarta majoring in Medical Records Program Study.Method: This research used qualitative research to collect empirical data from the students' written works. Results: In this research, it was found that 1) in investigating types of grammatical errors in students' written works, it can be inferred that there are 417 errors that occurred in students' written works. It was found 40 types of grammatical errors in this study. 2) In figuring out how mother tongue interference effects on students' written works. It was found 66 or $15.83 \%$ was caused by mother tongue interference or interlingual errors. Errors due to mother tongue interference were categorized into three: (i) word-by-word translation, it was found 14 or $21 \%$ errors, (ii) using Indonesian construction in English, it was counted 21 or $32 \%$, (iii) using adjectives as main verbs, 31 or $47 \%$ errors were found. 3) In revealing why such errors occur in students' written works. We found two general causes of errors in students' written works. Conclusions: The total grammatical errors found in students' written works were 417 errors, $351(84.17 \%)$ errors were caused by intralingual errors, and 66 (15.83\%) errors were caused by interlingual errors.
\end{abstract}

Keywords: Students' grammatical errors; students' written works; interlingual and intralingual

\section{Introduction}

A language unifying countries in the world is English. It is the most widely used in the world. It means that mastering English well is very important. English is one of a means of international communication, and people have been using English, either informal or formal situations [1]. We know that some countries in the world use English as their mother tongues such as England, America, New Zealand, Australia, and etc. Some countries such as Singapore, France, China, India, Philippine, Malaysia, and etc. use English as their second language. But in Indonesia, English is a foreign language [2]. Atashian [3] points out, "Foreign language is a language which is taught as a school subject but which is not used as a medium of instruction in schools nor as a language of communication within a country.
Based on its theory, we can say that English which students learn in schools is as a foreign language, they do not use it in their daily communication or life, it is only as a compulsory subject which they have to learn. Since English is a foreign language, it is realized that most Indonesian students generally get some difficulties in learning it $[2,4]$. The difficulties occur when the students lack knowledge about vocabulary and grammar. They are claimed to master language skills such as listening, speaking, reading, and writing. Teachers and students should realize the importance of English language development, particularly in the part of writing skills. The reason is that writing is one of the language skills used to express ideas and thoughts. Thus, being able to express ideas and thoughts using appropriate grammar is essential for the skillful writers in order to share 
their opinions and thoughts to the readers as they intend to convey [5-7]. Writing is a difficult process, even in the first language. It is even more complicated to write in a foreign language. Many studies indicate for the beginning English foreign language students, and there tends to be interference from their first language in the process of writing in English. Writing in a foreign language often presents the greatest challenge to the students at all because it is integral to the learning process, and it can improve the students' academic performances.

Jasim Al-Shujairi [8] states that writing skill requires more capabilities than other language skills and needs special preparation. Writing requires students to understand the spellings, the punctuations, the grammar rules, the vocabularies, and paragraph development. Because of that, writing is one of the four skills which have high status as a part of the culture of society or institution. It means that writing is one of the communicational means by which the students can communicate their ideas and thoughts. It involves composing, which implies the abilities either to tell or to retell pieces of information in the forms of narration, description, or transform information into texts. Writing has big advantages over speaking. Through writing, it gives us time to think, to try out ideas on pieces of paper, to read what has been written, to revise and arrange. The most important is to find what the writer means [9]. It means that the students should choose suitable words to be arranged into sentences and determine the right verb that is suitable for the tense. It also means that the students have time to prepare their writing, then they are going to write, revise, and arrange into a good composition. Although writing is easier than speaking, the students still say that writing is difficult because English rules are very complicated, and they differ from their native language. They often make incorrect structures or break the language rules. They still use Indonesian English in their sentences. In fact, a wrong sentence can disturb the meaning of the sentence [2].

Moreover, it was found in many prior papers that writing is the main obstacle that English foreign language and English second language students encounter. These include the environment, age, teacher's motivation, students' attitude, and parents' attitude. Due to the fact that English foreign language and English second language students encounter a syntactic problem in writing, it is difficult to convey their ideas and thoughts accurately and appropriately. For Indonesian students, vocabularies and grammatical rules seem to cause a lot of difficulties in their academic writings. Hence, the study of syntactic errors is necessary, and it would be beneficial for English foreign language and English second language teaching in order to develop the students' English writings and raise their awareness, especially when the native language has influenced on the productions of students' academic English writings in terms of negative syntactic transfer [10].

Writing in general and essays in particular forms make some problems to the second-semester students of Polytechnic Indonusa Surakarta, majoring in Medical Records. English lecturers at Polytechnic Indonusa Surakarta are generally faced with students who have memorized a good amount of vocabulary and grammatical rules. In many cases, the majority of these students are still translating words, phrases, and sentences from Indonesian into English with often very strange results. The challenge of English lecturers is to find methods to activate in a meaningful way the passive knowledge that the students possess in terms of the writing skill as well as to help students become more proficient while working to eliminate some of their common errors. A better understanding of the first language influence in the process of English foreign language writing helps lecturers know students' difficulties in learning English [8,11-12]. Writing is one of four language skills that have to be mastered by students well, and writing is also an essential skill in this era so that the students are claimed to master the writing skill fluency and accuracy [13].

Nowadays, a lot of information from other countries is given in the written forms, and we have to reply to them in written forms too. There are some reasons why mastering writing skills is very important. First, when the students master the writing skill well, fluency and accuracy, it will improve their English fast and 
also improve their careers in the future. Besides, when students are good at writing skills, what they want to deliver in the written form will be understood well and clearly by the readers. Moreover, when the students do some academic writings (papers, essays, compositions, theses, and etc.), job-related writings (messages, letters, reports, advertisements, and etc.), and personal writings (notes, invitation, personal letters, medical reports, and etc.), their work can be understandable clearly so everything will run well.

However, most students say that it is difficult to write essays; some of the various types of errors are found though they have had a lot of vocabulary and grammatical rules. Therefore, English lecturers need to anticipate certain common types of errors. They may also find other types of errors, which can be revealed by analyzing the written products or essays of the students. These are the conventions, which are usually followed by the English lecturers when analyzing students' errors. Writing skill involves many other sub-skills such as the general knowledge about the subject in the question and ability to translate ideas into grammatical sentences. English foreign language students have to think about all of those that they need to apply or use. English foreign language students are more prone to committing errors. English lecturers are currently feeling the challenge of adopting and developing a wide range of methods to accomplish effective teaching of English writing. Students at Polytechnic Indonusa Surakarta have been starting learning English since they were in the first junior high schools even some in elementary schools they have spent more than seven years of learning the English language. So they are expected to have understood intermediate, even advanced English.

In spite of the fact that they have been studying English for more than seven years and their vocabularies are expected to be massive, and their knowledge of grammatical rules are satisfying, most of the students are still not able to write a correct paragraph using adequately basic structures of the English language they have learned. In light of this introduction, the main aim of this study is to explore and analyze the common grammatical errors in students' written works.

\section{Material and Methods}

This research used qualitative research. Qualitative research is research that uses words, sentences, schemes, and pictures to perform the result of the research. This does not stress meaning by using numerically measured data, but it stresses meaning by the [14]. In carrying out this study, the researcher worked in identifying, describing, categorizing, and explaining, and evaluating grammatical errors [15]. The aim of this study was to describe the types and causes of errors. For this purpose, the data were collected from students and identified students' written works to find grammatical errors in students' writings and then categorized the errors into each category, quantified each item of errors to obtain a percentage of each error, and explained grammatical errors to identify the causes or errors.

To collect the data, students were asked to complete written works. They were given optional topics, and each of them had to choose one provided topic. Each written work should be at least consisting of 200 words. In addition, they were allowed to open a dictionary to make sure that they wrote each word correctly. In doing this written work, students did not need specific preparation.

They completed the written works under their present condition at the time when the researcher came to the class to give the assignment. This spontaneous production was expected to produce authentic data. In order to analyze types of various grammatical errors in students' written works, the errors were identified and categorized into different error types. Every sheet of the students' written works was analyzed. In identifying the data, we used the instrument of error identification. The errors were marked by giving underlines. After all, errors were identified, then the frequency of each type of error was investigated. The frequency of errors was calculated and presented using the following formula:

Note: 


\section{P: Percentage}

e : Number of errors of each type

$t$ : Total of errors

After the frequency of errors was calculated, the results would be presented in a tabular form. The table would present the number of errors and percentages. The common features of each type of errors found in students' written works were investigated and described in detail, and the examples of such features would be given. The causes of these errors found in students' written works were explored, and the explanation would be given. The causes of these errors found in the students' written works were explained regarding the mother tongue interference aspects. The findings were grouped, and the examples found in students' written works were presented.

\section{Results and Discussion}

Based on the errors found, the researcher is going to divide the students' grammatical errors in Supplementary 1. Based on Supplementary 1 , a number of different grammatical errors were found in their written works. Students made 417 errors in their descriptive written works and those errors were classified into categories. It was found 40 types of grammatical errors that 62 or $14.86 \%$ was plural nouns, 47 or $11.27 \%$ was subject verb agreement, 36 or $8.63 \%$ was be forms, 36 or $8.63 \%$ was word choices, 33 or $7.91 \%$ was fragments,
32 or $7.67 \%$ was tenses, 28 or $6.71 \%$ was articles, 17 or $4.07 \%$ was base forms, 15 or $3.60 \%$ was prepositions, 14 or $3.36 \%$ was verbs, 10 or $2.40 \%$ was auxiliary verbs, 9 or $2.16 \%$ was gerunds, 8 or $1.92 \%$ was parallel plural nouns, 7 or $1.68 \%$ was infinitives, 6 or $1.44 \%$ was word orders, 5 or $1.20 \%$ was zero articles, 4 or $0.96 \%$ was adjective pronouns, 4 or $0.96 \%$ was adjectives, 4 or $0.96 \%$ was past participles, 4 or $0.96 \%$ was subjects, 3 or $0.72 \%$ was determiners, 3 or $0.72 \%$ was adjective clauses, 3 or $0.72 \%$ was adverbs, 3 or $0.72 \%$ was antecedents, 3 or $0.72 \%$ was quantifiers, 3 or $0.72 \%$ was singular nouns, 2 or $0.48 \%$ was adverb places, 2 or $0.48 \%$ was comparison, 2 or $0.48 \%$ was negatives, 2 or $0.48 \%$ was paired conjunctions, 1 or $0.24 \%$ was coordinate conjunctions, 1 or $0.24 \%$ was negatives in purposes, 1 or $0.24 \%$ was nouns, 1 or $0.24 \%$ was object pronouns, 1 or $0.24 \%$ was parallel nouns, 1 or $0.24 \%$ was possessions, 1 or $0.24 \%$ was present participles, 1 or $0.24 \%$ was question words, 1 or $0.24 \%$ was reflexive pronouns, 1 or $0.24 \%$ was uncountable nouns.

\section{Figuring out how mother tongur interfer- ence effects on students' written works}

Regarding the study, we found 66 (15.83\%) interlingual errors, which were caused by mother tongue interference. The features of interference errors could be categorized into Table 1 :

Table 1. Word-by-words translation

\begin{tabular}{lll}
\hline No & \multicolumn{1}{c}{ Incorrect sentences } & \multicolumn{1}{c}{ Indonesian sentences } \\
\hline 1 & Living in a place is depend with & Tinggal di sebuah tempat tergantung dengan \\
2 & We can find this people & Kita dapat mendapati orang-orang ini \\
3 & A half from human & Separuh dari manusia \\
4 & One kilograms rice & Satu kilogram beras \\
5 & The effect from smoking & Efek dari merokok \\
\hline
\end{tabular}

From Table 1 above, students just translated from Indonesian into English. They looked from the English words, which had the same meaning as in Indonesian. However, they may be more than one word with similar meaning. Therefore, students should know how each word is used in the context. If students trans- late word-by-word from Indonesian into English, it can lead to incorrect or inappropriate sentences, as shown in the table above. Based on the Table 2 above, students may not or be concerned much about the difference between Indonesian and English construction. For example, Indonesian does not have a past tense, 
but English has. In English, an adjective describes a noun, but in Indonesian, a noun describes an adjective. Students need to learn much about the difference between Indonesian and English construction. It is possible that students make such errors because of mother tongue interference.

Table 2. Using Indonesian construction in English

\begin{tabular}{lll}
\hline No & \multicolumn{1}{c}{ Incorrect sentences } & \multicolumn{1}{c}{ Indonesian sentences } \\
\hline 1 & Why people have a different ability? & $\begin{array}{l}\text { Mengapa manusia mempunyai keterampilan yang } \\
\text { berbeda-beda? }\end{array}$ \\
2 & Because tired & Karena kecapaian \\
3 & For people who near the smoker & Untuk orang-orang yang dekat dengan perokok \\
4 & The quality education & Kualitas pendidikan \\
5 & It because & Itu karena \\
\hline
\end{tabular}

Table 3. Using adjectives as main verbs

\begin{tabular}{|c|c|c|}
\hline No & Incorrect sentences & Indonesian sentences \\
\hline 1 & Will hard & Akan sulit \\
\hline 2 & $\underline{\text { It hard }}$ & Itu sulit \\
\hline 3 & Citizens in a big city will easier to buy & $\begin{array}{l}\text { Masyarakat di kota besar akan lebih mudah untuk } \\
\text { membeli }\end{array}$ \\
\hline 4 & If we sick & Jika kita sakit \\
\hline 5 & We have to smart & Kita harus pintar \\
\hline
\end{tabular}

From the Table 3 above, many adjectives are used as main verbs due to the influence of Indonesian grammatical patterns. In English, verb be is used with an adjective while in Indonesian, no form of the verb be is used with an adjective.

Table 4. Revealing why such errors occur in students' written works

\begin{tabular}{|c|c|c|}
\hline No & Identification of errors & Explanation of errors \\
\hline 1 & $\begin{array}{l}\text { We usually see trader, } \\
\text { doctor, manager, presi- } \\
\text { dent, scientist, and so- } \\
\text { on. }\end{array}$ & $\begin{array}{l}\text { - Intralingual } \\
\text { It is caused by a lack of grammatical competence of paral- } \\
\text { lel plural nouns. A suffix - s/es has to attach into the par- } \\
\text { allel countable nouns to make them become plural nouns. } \\
\text { Those nouns should be plurals in order to talk about } \\
\text { something in general. }\end{array}$ \\
\hline
\end{tabular}

2 Why people have a different ability?

Interlingual

The auxiliary verbshould be used after the question word why. This case is the influence of Indonesian question rules, which do not need an auxiliary verb to make a question using question words.

3 Why people have a dif- - Intralingual ferent ability?

It is caused by a lack of grammatical competence of plural nouns. A suffix - es has to attach into the word ability to make it become a plural noun. It should be plural in order to talk about abilities in general.

Continued.... 


\begin{tabular}{|c|c|c|}
\hline No & Identification of errors & Explanation of errors \\
\hline 4 & $\begin{array}{l}\text { So education has the } \\
\text { ability to determine }\end{array}$ & $\begin{array}{l}\text { - Intralingual } \\
\text { An article has to apply to a singular countable noun and } \\
\text { an article an should be applied in front of the word ability } \\
\text { because the initial sound is a vowel. The student is lack of } \\
\text { grammatical competence in applying articles. }\end{array}$ \\
\hline 5 & Will hard & $\begin{array}{l}\text { - Interlingual } \\
\text { The verb has to be used after the model will because it is } \\
\text { followed by an adjective. It is like Indonesian rules which } \\
\text { do not need to be after a modal. }\end{array}$ \\
\hline
\end{tabular}

We found two general causes of errors in students' written works. The first is interlingual errors. It is caused by the differences between Indonesian and English rules or the influences of the students' language. It makes difficulties to students, and they tend to produce a negative transfer from Indonesian into English. In fact, the rules of Indonesian and English are different. The second is intralingual errors. It is known that many intralingual errors occur in students' sentences. The errors are particularly in the area of grammars or structures of the target language. The total grammatical errors found in students' written works were $417 \mathrm{er}$ rors, $351(84.17 \%)$ errors were caused by intralingual errors, and 66 (15.83\%) errors were caused by interlingual errors.

1) Adjective clauses. It was found $3(0.72 \%)$ errors.

2) Adjective pronouns. Students made 4 $(0.96 \%)$ errors.

3) Adjectives. The percentage of errors in adjectives was $0.96 \%$ ( 4 errors).

4) Adverb places. Errors in the adverb places were $2(0.48 \%)$.

5) Adverbs. It was $2(0.48 \%)$ errors.

6) Antecedents. The percentage of errors in antecedents was $0.72 \%$ ( 3 errors).

7) Articles. The total number of errors counted in articles was 28 or $6.71 \%$.

8) Auxiliary verbs. Students made 10 (2.40\%) errors.

9) Base forms. students made 17 errors or $4.07 \%$.

10) Be forms. there were $36(8.63 \%)$ errors.

11) Comparisons. It was found two errors of comparisons, and the percentage was 0,48 .
12) Coordinate conjunctions. One error was found.

13) Determiners. 3 or $0.72 \%$ of errors were found.

14) Fragments. 33 (7.91\%) were noticed as fragments.

15) Gerunds. Errors of gerunds found in this study were 9 or $2.16 \%$.

16) Infinitives. Errors in infinitives were seven or it was $1.68 \%$.

17) Negatives. The percentage of errors in negatives was $0.48 \%$; it meant only two.

18) Negatives in purposes. It was one error.

19) Nouns. The percentage of errors in the use of nouns was $0.24 \%$ (one error).

20 ) Object pronouns. It was only a $0.24 \%$ or one error.

21) Paired conjunctions. It was found two errors or $0.48 \%$.

22) Parallel nouns. One error or $0.24 \%$ was found in this study.

23) Parallel plural nouns. Errors in parallel plural nouns were $8(1.92 \%)$.

24) Past participles. $0.96 \%$ or 4 errors.

25) Plural nouns. 62 errors (14.86\%) were counted.

26) Possessions. 1 error or the percentage was $0.24 \%$.

27) Prepositions. The total errors were 15 or $3.60 \%$.

28) Present participles. 1 or $0.24 \%$ error was found.

29) Quantifiers. The findings of errors in the use of quantifiers were $3(0.72 \%)$.

30) Question words. 1 or $0.24 \%$.

31) Reflexive pronouns. 1error, and the percentage of errors was $0.24 \%$. 
32) Singular nouns. Three errors and error rate of $0.72 \%$.

33) Subject-verb agreement. This was the second-highest with 47 errors $(11.27 \%)$.

34) Subjects. 4 or $0.96 \%$ errors were found.

35 ) Tenses. 32 or $7.67 \%$ of errors were found.

36) Uncountable nouns. It was only found one error or $0.24 \%$.

37) Verbs. Errors in the use of verbs were found 14; they constituted $3.36 \%$.

38) Word choices. 36 or $8.63 \%$ of errors were counted.

39) Word orders. 6 errors (1.44\%).

40) Zero articles. It was found five errors of zero articles or $1.20 \%$ of errors.

Regarding the study, we found 66 (15.83\%) interlingual errors, which were caused by mother tongue interference. Hamdi [17] states that second language learners are strongly influenced by the learners' first language. It is also supported by Hourani [18], interlingual errors are those which are related to the native language. The features of interference errors could be categorized into three: (1) word-by-word translation, (2) using Indonesian construction in English and, (3) using an adjective as main verbs.

1. Word-by-word translation

a) We can find this person Kita dapat mendapati orang-orang ini

b) Half from human separuh dari manusia

From the examples above, students just translated from Indonesian into English. They looked from the English words, which had the same meaning as in Indonesian. However, they may be more than one word with similar meaning. Therefore, students should know how each word is used in the context. The different language structures are another factor leading to words to words translation in second language production [8]. If students translate word-byword from Indonesian into English, it can lead to incorrect or inappropriate sentences, as shown in the examples above.

2) Using Indonesian construction in English

3) Because tired Karena kecapean

4) For people who near the smoke untuk orang-orang yang dekat dengan perokok

Based on the examples above, students may not or be concerned much about the different between Indonesian and English construction. For example, Indonesian does not have a past tense, but English has. In English, an adjective describes a noun, but in Indonesian, a noun describes an adjective. Students need to learn much about the different between Indonesian and English construction. It is possible that students make such errors because of mother tongue interference. The differences of grammatical rules between Indonesian and English take a big part of making errors so mastering grammatical rules is a must for students. Grammar is an intrinsic meaning marker of a language that rules in arranging a set of words in order to form meaning [19].

1) Using adjectives as main verbs If we sick Jika kita sakit

2) It more useful right? Itu lebih berguna, kan?

From the examples above, many adjectives are used as main verbs due to the influence of Indonesian grammatical patterns. In English, verb be is used with an adjective while in Indonesian, no form of the verb be is used with an adjective. Malak [20] points out that when learning a foreign language, an individual already knows his mother tongue, and it is which he attempts to transfer. The transfer may prove to be justified because the structures of the two languages are similar in this case, we get a positive transfer, or it may prove unjustified because the structures of the two languages are different in this case we get negative transfer or interference. Revealing out why errors occur, we found two reasons why errors occur in students' written works. Firstly, it is a lack of grammatical understanding. Solihat [21] emphasizes the importance of grammar mastery to support the good use of language. In addition, Jasim Al-Shujairi[8] declares that grammatical knowledge is very important for students who want to have communicative competence. With a good understanding of grammatical concepts, students can avoid the use of incorrect structures. Secondly, students more 
likely translated Indonesian into English without taking notice of the grammars. Singh [1] said errors made by students are predicted by identifying the linguistic differences between their first language and the target language. Interference was believed to be the main cause of error production when the students transferred native language habits into the target language.

\section{Conclusion}

In investigating types of grammatical errors in students' written works, it can be inferred that there are 417 errors that occurred in students' written works, and those errors were classified into categories. It was found 40 types of grammatical errors in this study. It can be known that the plural nouns were the highest frequency of grammatical errors, and uncountable nouns were the lowest frequency of grammatical errors that occurred in students' written works of descriptive text.

Besides, in figuring out how mother tongue interference effects on students' written works. It was found 66 or $15.83 \%$ was caused by mother tongue interference or interlingual errors. Errors due to mother tongue interference were categorized into three: (I) word-by-word translation, it was found 14 or $21 \%$ errors, (II) using Indonesian construction in English, it was counted 21 or $32 \%$, (III) using adjectives as main verbs, 31 or $47 \%$ errors were found. Meanwhile, in revealing why such errors occur in students' written works. We found two general causes of errors in students' written works. The total grammatical errors found in students' written works were 417 errors, 351 (84.17\%) errors were caused by intralingual errors, and $66(15.83 \%)$ errors were caused by interlingual errors. So, it can be inferred that the grammatical errors in students' written works were caused by a lack of grammatical understanding, and students more likely translated Indonesian into English without taking notice of the grammars.

\section{Acknowledgment}

This work was financially supported by Research Center for Biomaterials through "DIPA 2017". Therefore, we are grateful for this funding and support of this research.
The authors are highly indebted to the Head of Program Study of Medical Record and the Head of Program Study of Mass Communication, Polytechnic Indonusa of Surakarta, Indonesia. Also, Mrs. SuciPurwandari, as a Director of Polytechnic Indonusa Surakarta, Indonesia, has funded this research.

\section{References}

1. Singh CKS, Jageer Singh AK, Abd Razak NQ, Ravinthar T (2017) Grammar errors made by ESL tertiary students in writing. Engl Lang Teach. 10(5):16-27. https://doi.org/10.5539/elt.v10n5p16

2. Mustafa F, Kirana M, Bahri YS (2016) Errors in EFL writing by junior high students in Indonesia. IJRSLL 5(5):37-50. https://doi.org/10.5861/ijrsll.2016.136

3. Atashian S, Al-Bahri K (2018) Towards Arab students' grammatical errors in academic writing $\&$ their perceptions. AWEJ 1:140-145. https://doi.org/10.24093/awej/mec1.10

4. Hamzah H (2012) An analysis of the written grammatical errors produced by freshment students in english writing. Lingua Didaktika: Jurnal Bahasa dan Pembelajaran Bahasa 6(1):17. https://doi.org/10.24036/ld.v6i1.3127

5. Watcharapunyawong S, Usaha S (2013) Thai EFL students' writing errors in different text types: the interference of the first language. Engl Lang Teach. 6(1):67-78. https://doi.org/10.5539/elt.v6n1p67

6. Krishnasamy J (2015) Grammatical error analysis in writing of ESL diploma students. AJEEL 3(1):2321-2454. https://www.ajouronline.com/index.php/AJEEL/article/vi ewFile/2305/1233

7. Sermsook K, Liamnimitr J, Pochakorn R (2017) An analysis of errors in written english sentences: a case study of Thai EFL students. Engl Lang Teach. 10(3):101. https://doi.org/10.5539/elt.v10n3p101

8. Jasim Al-Shujairi YB, Tan H (2017) Grammar errors in the writing of Iraqi english language learners. IJELS 5(4):122. https://doi.org/10.7575/aiac.ijels.V.5n.4p.122

9. Effendy E (2014) An error analysis in writing descriptive text. Surakarta, Universitas Muhammadiyah Surakarta.

10. Rosmaladewi R, Abduh A (2017) Collaborative teaching cultures of english lecturers in Indonesian Polytechnics. IJOLE 1(1). https://doi.org/10.26858/ijole.v1i1.2868

11. Vethamaiccam M, Ganapathy M (2017) Analysing errors among form one students' written english composition in a private chinese school. AJEEL 5:6-26.

12. Abdullah NAJB (2017)An analysis of the grammatical errors made by FLEE2113 students and the relation with L1 interference. National Pre University Seminar 2017. 2017:288-299. 
13. Sianna S, Syawal S (2017) The implementation of poew in teaching writing. IJOLE 1(1) https://doi.org/10.26858/ijole.v1i1.2871

14. Susanti R, Sumarlam S, Djatmika D, Rohmadi M (2018) Responses to caring speech acts: the politeness strategies of Indonesian students in academic activities. Proceedings of the Fourth Prasasti International Seminar on Linguistics (Prasasti 2018). https://doi.org/10.2991/prasasti18.2018.77

15. Chang YF (2006) An inquiry into pragmatic data collection methods. https://eric.ed.gov/?id=ED508832

16. Owu-Ewie C, Williams MR (2017) Grammatical and lexical errors in students' english composition writing: the case of three senior high schools (SHS) in the Central Region of Ghana. Sino-US English Teaching, 14(8):463-482. doi.org/10.17265/1539-8072/2017.08.001
17. Hamdi S (2005) An analysis of written grammatical errors of Tunisian learners of English in EFL context. Tunisia, ISEAH Institute of Kef.

18. Hourani TM (2008) An analysis of the common grammatical errors in the english writing made by 3rd male secondary students in the Eastern Coast of the UAE. Dissertation. Institute of Education, British University in Dubai.

19. Basra SM, Thoyyibah L (2017) A speech act analysis of teacher talk in an EFL classroom. International Journal of Education,

10(1):73. https://doi.org/10.17509/ije.v10i1.6848

20. Fhaid Alqhtani M (2018) Investigating syntactic errors among Saudi EFL learners. AWEJ: 1-52. https://doi.org/10.24093/awej/th.204

21. Solihat D, Novianti D (2015) Error analysis of writing verbs in discussion text. ERJEE 4(1):75. https://doi.org/10.25134/erjee.v4i1.309 